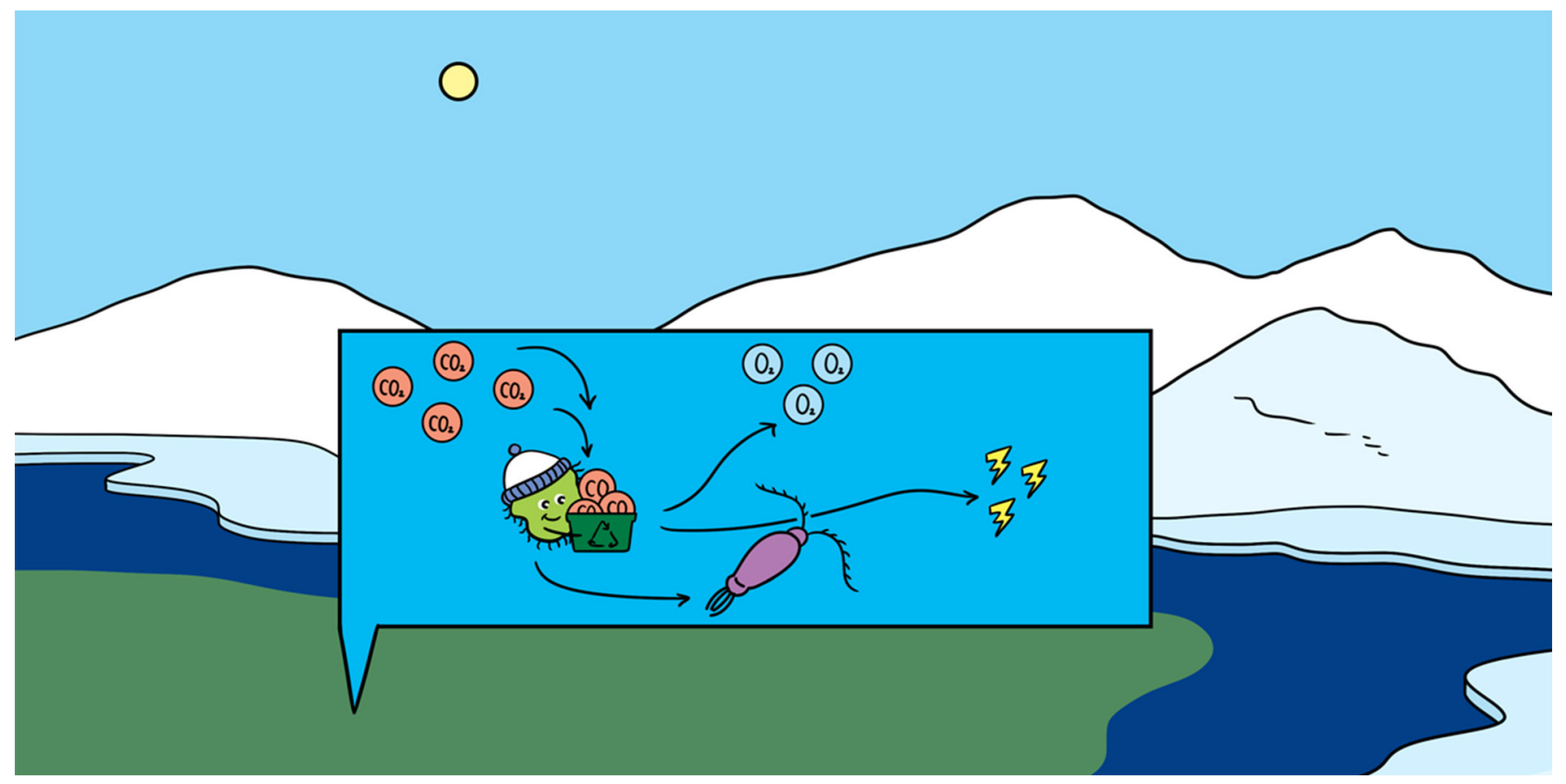

\title{
REDUCE, REUSE, RECYCLE IN THE ARCTIC OCEAN WITH THE POWER OF MICROBES
}

\author{
Birthe Zäncker ${ }^{1+}$, Rowena F. Stern ${ }^{1 * t}$, Elliott L. Price ${ }^{1,2}$ and Michael Cunliffe ${ }^{1,3}$ \\ ${ }^{1}$ Marine Biological Association, Plymouth, United Kingdom \\ ${ }^{2}$ School of Environmental Sciences, University of Liverpool, Liverpool, United Kingdom \\ ${ }^{3}$ School of Biological and Marine Sciences, University of Plymouth, Plymouth, United Kingdom
}

YOUNG REVIEWERS: MODBURY PRIMARY SCHOOL AGES: $10-11$
Did you know that microbes, too small for the human eye to see, far outnumber and outweigh all animals? Microbes that live in the Arctic carry out a surprising variety of roles recycling food. Despite the cold temperatures, Arctic waters are nutrient rich, which allows a type of microbe called single-celled algae to grow in huge numbers. Only cold-adapted microbes can survive though in waters that sometimes reach temperatures even below freezing! Microscopic algae use carbon dioxide $\left(\mathrm{CO}_{2}\right)$ and the sun's energy to grow, helping to reduce levels of $\mathrm{CO}_{2}$ in the atmosphere. Microscopic animals called zooplankton eat smaller microbes. All microbes excrete waste and eventually die. The resulting products are not wasted, though. Other microbes called bacteria and fungi are expert recyclers and break down the dead organisms to more basic forms of chemical energy that are reused by single-celled algae and other microbes. 


\section{MICROBES}

A variety of single-celled organisms including algae, bacteria, viruses, and fungi. Algae can use photosynthesis to make complex nutrients like sugar from sunlight and carbon dioxide $\left(\mathrm{CO}_{2}\right)$. Carnivorous microbes help recycle nutrients.

\section{ZOOPLANKTON}

Microscopic animals that eat microbes. Zooplankton are primary consumers.

\section{ALGAE}

Algae are plants living in the water. They can range from single-celled organisms (see microbes) to huge plants up to several meters high. Just like plants on land they need sunlight to survive.

\section{WHY ARE MICROBES SO IMPORTANT?}

Microbes are microscopic organisms that are formed from a single cell. Did you know that $1 \mathrm{~L}$ of seawater contains billions of microbes [3]? Due to the sheer size of our oceans, this means that there are 100 billion times more microbes in the oceans than there are stars in the known universe! There are thousands of types of microbes that researchers are still discovering. Some are carnivores, some are herbivores, and some are omnivores, like fungi, bacteria, zooplankton, and phytoplankton. Microbes are the base of the food web and support all larger organisms, because of their sheer numbers. In fact, marine microbes make up $70 \%$ of the total living mass of all oceans [1]!

Microbes not only support all life as we know it, but they also play an important role in providing half of the oxygen we breathe and regulating the earth's climate. Some microbes can take up $\mathrm{CO}_{2}$, a gas that can trap heat in our atmosphere and contribute to global warming. Thanks to microbes, the deep ocean and sediments contain almost half as much $\mathrm{CO}_{2}$ as we can find in the atmosphere. $\mathrm{CO}_{2}$ trapped in the deep ocean cannot contribute to global warming, so $\mathrm{CO}_{2}$ uptake by the oceans is good for our planet. The $\mathrm{CO}_{2}$ uptake is not the same across all oceans though. The Arctic Ocean tends to take up an especially large amount of this gas. Despite the importance of the Arctic Ocean for regulating the $\mathrm{CO}_{2}$ in our environment, we know very little about this ocean.

\section{WHY DO WE KNOW SO LITTLE ABOUT LIFE IN THE ARCTIC?}

Learning about the Arctic and the organisms that live there is extremely difficult because this ocean is largely inaccessible. For much of the year, thick ice prevents any ships from entering and the weather is too rough to carry out experiments. Because of this, we only see snapshots of the processes that happen in the Arctic, mostly in the summer months. Conditions in the Arctic Ocean are hostile, with long, freezing winters and short, cool summers. Average air temperatures in winter can fall to $-34^{\circ} \mathrm{C}$ and rise up to $10^{\circ} \mathrm{C}$ in the summer, although the ocean temperature remains steady at around -1.5 to $-3^{\circ} \mathrm{C}$. Much of the water is locked up as ice. Depending on how far north you are, there can be up to almost half a year of complete darkness during the winter, or 24-h of daylight during the summer.

A lot of microbes live in or attached underneath sea ice. The ice that forms on the Arctic Ocean is not as solid as you might think. Numerous tiny water channels permeate the ice (Figure 1). These channels carry very salty water and are called brines. Lots of microbes, including algae, fungi, and bacteria, live and eat in the brines. 
Figure 1

A typical Arctic

food web. The arrows and lines show

connections between animals, microbes, and the food/nutrients they consume. The microbial loop (__ begins with primary producers producing organic matter. Carbon drawdown $(\rightarrow$ ) shows food waste or excreted matter sinking to the bottom of the ocean. Transparent exopolymer particles (TEP) help with carbon drawdown and are a food source for microbes, recycling energy into the microbial loop. Primary consumers like zooplankton feed on microbes and in turn are eaten by larger animals, transferring the energy to the top predators ( $\rightarrow$ ). Note: organisms not to scale.

\section{PRIMARY}

\section{PRODUCER}

Primary producers can directly use energy obtained from the sun or chemicals and use this energy to create cell building blocks like sugars and other nutrients.

\section{PHOTOSYNTHESIS}

Plants can use the energy from the sunlight. With the help of the sunlight, they take water, carbon dioxide and minerals and produce oxygen and sugars needed for cell growth. This process is called photosynthesis.

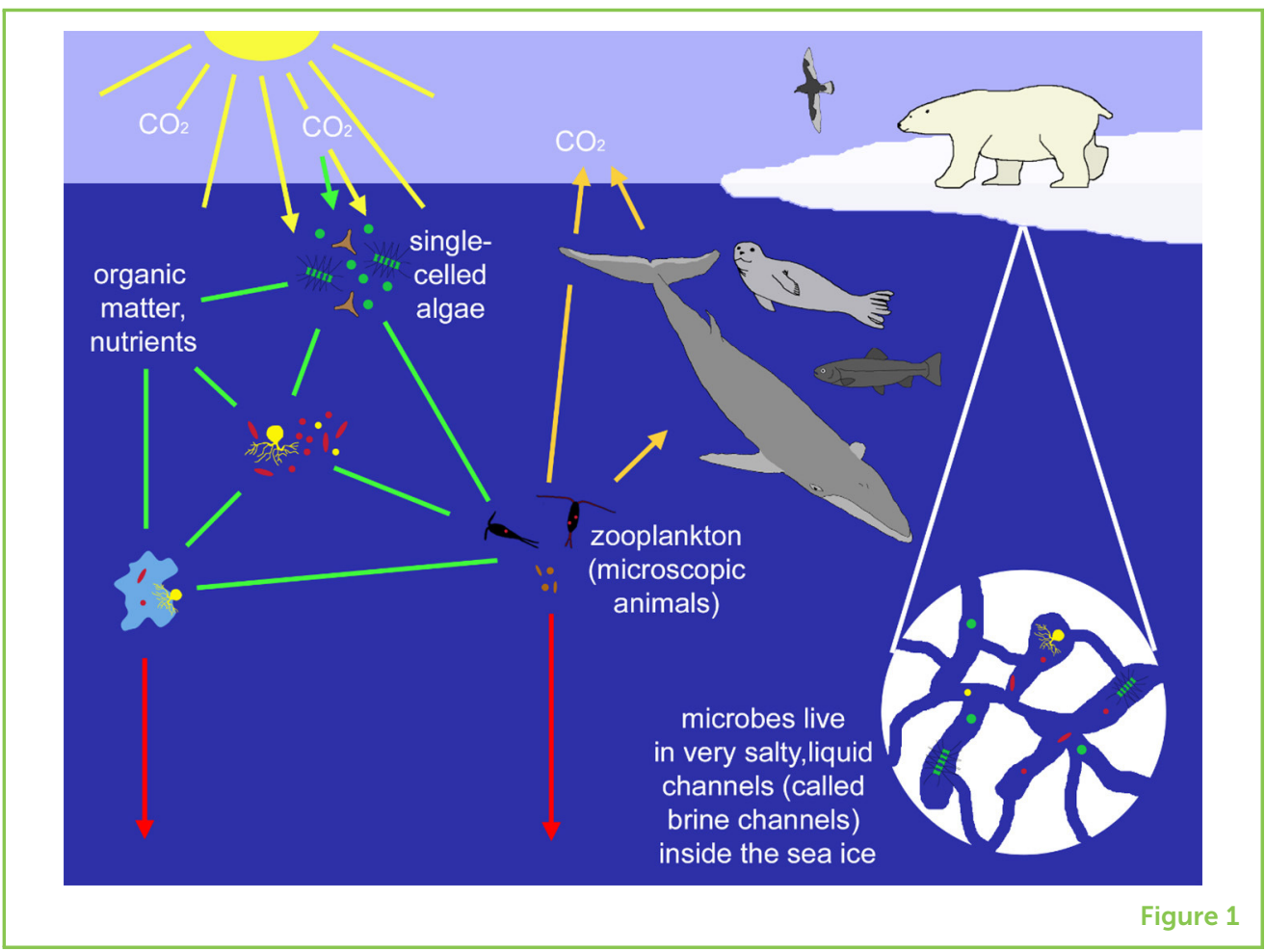

When scientists do get the rare chance to go to the Arctic on big research icebreakers, they need to prepare themselves thoroughly for the hostile conditions (Figure 2). Thick clothes are needed, and the scientists and crew must protect themselves from the harsh sunlight by wearing proper sunglasses and sunscreen. Even with all the precautions, the scientists still need to take breaks from working on the ice or on deck.

So, what do these harsh conditions mean for microbes that have to live in the Arctic all year round? Microbes have acquired several survival strategies to withstand the cold, such as making anti-freeze molecules to prevent ice from forming inside them, which would otherwise make them burst. Algae cells contain fats that help them to float on the surface, to capture the weak light during winter season. Other microbes go into hibernation, quite similar to some bears. In the spring and summer, microbes grow and reproduce to large numbers very quickly.

\section{HOW DO ARCTIC MICROBES REDUCE, REUSE, RECYCLE AND DECIDE HOW MUCH CO 2 FROM THE ATMOSPHERE REACHES THE SEDIMENT SEVERAL KILOMETERS BELOW THE OCEAN SURFACE?}

Single-celled algae are called primary producers, because they can live directly from sunlight without the help of other animals or plants. Through the process of photosynthesis, these algae can make sugars 
Figure 2

How we investigate Arctic microbes on the ship James Clark Ross. (Top) Birthe Zäncker (top middle) is finding out what types of fungi live on transparent exopolymer particles (TEP) and how they contribute to moving carbon into the deep ocean. (Bottom) Elliott Price uses special laboratory tests to identify what zooplankton have eaten and the amount of nutrients they have obtained (pictures courtesy of E. Price, J. Hopkins, R. Jeffries, L. Norman, B. Zäncker, D. Conway).

\section{PRIMARY}

\section{CONSUMER}

A primary consumer eats primary producers



Collect water deep in the ocean with TEP and fungi growing on TEP
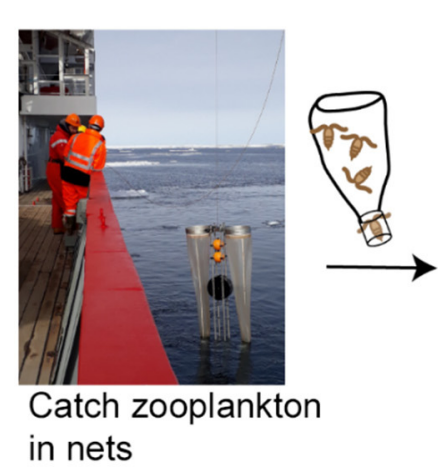

Catch zooplankton

in nets

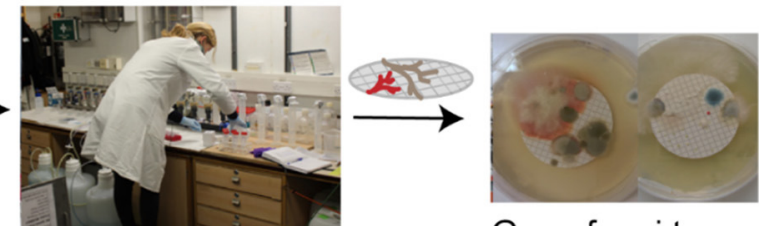

Grow fungi to identify them with
Pour the water through

a filter to collect fungi

\section{DNA tests}

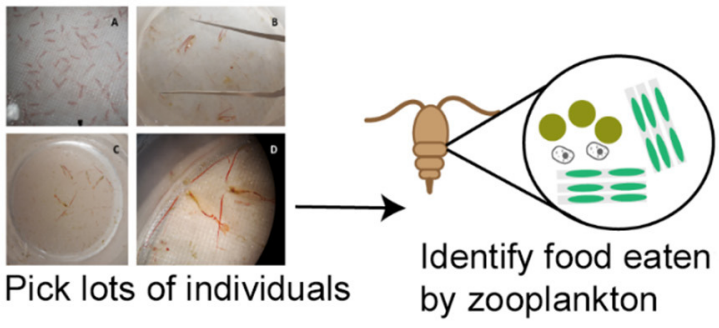

Pick lots of individuals by zooplankton

and other compounds from $\mathrm{CO}_{2}$, using water and sunlight. All other organisms depend on these algae as a source of food. Zooplankton are primary consumers, which means that they directly eat the algae, the primary producers (instead of eating other animals), and they can grow in huge swarms. Whales, seals, and fish eat zooplankton, and finally, top predators, such as polar bears feed on the fish and seals. Figure 1 shows a summary of a typical Arctic food web.

Not all the food is eaten though, and the leftover food turns into waste. In addition, just like us, microbes have to poop. All that waste cannot simply be flushed down the toilet. Microbes help with disposal of waste, especially in the summer when growth is at its highest. Specialized microbes, such as some bacteria and fungi, can break down leftover food into small particles that contain essential nutrients. These particles can be eaten by other microbes, such as algae, so that the whole process can start again, thus re-using the nutrients once again and reducing the waste that sinks to the bottom of the ocean. What about the $\mathrm{CO}_{2}$ that is produced by millions of microbes as a waste product? This is recycled by algae as they grow and perform photosynthesis. The overall gain or loss of $\mathrm{CO}_{2}$ in the ecosystem depends on the balance between its creation as a waste product and its use in the process of photosynthesis.

Did you know that fungi not only grow in forests, where we can see them growing as mushrooms on old tree branches, but they also grow abundantly in the ocean? Just like in the forest, marine fungi help to break down dead organisms and the waste products from living cells. 


\section{CARBON}

DRAWDOWN

The process of carbon being drawn down to the bottom of the ocean when food or animals sink (called marine snow), removing the carbon from the ocean's surface.
In the ocean, fungi shapes range from simple, round cells to cells with tiny tentacles called hyphae (Figure 1), which help the fungi to attach to other organisms and particles.

The recycling of waste does not work perfectly, though. The melting sea ice makes the water cold and less salty. This produces very dense water that sinks to the bottom of the ocean, taking with it particles and organisms suspended in the cold water before the microbes at the surface have time to recycle it. When they reach the bottom of the water column, these particles and organisms become trapped in the sediment, locked away for millions of years. This is called carbon drawdown (Figure 1). Carbon drawdown is beneficial because the carbon is kept out of the atmosphere and does not trap the heat around our Earth.

In addition to marine microbes, researchers have found that jelly-like particles, called transparent exopolymer particles (TEP) also play an important role in carbon drawdown. The TEP are very sticky and can trap cells and other particles on their surfaces. These clumps can get heavy and sink quite rapidly down into the deep ocean, bringing carbon-containing molecules into the deep ocean, also benefiting the atmosphere.

\section{HOW DO WE TRACK THE RECYCLING OF MICROBIAL WASTE IN THE ARCTIC OCEAN?}

We need to understand how the recycling of carbon in the surface layer of the ocean works to predict how climate change will affect this process in the future. Climate change describes the warming of the Earth. Over the last century, the Earth has warmed by $0.87^{\circ} \mathrm{C}$ on average [2] due to an increase in $\mathrm{CO}_{2}$ from human activity. This might not seem like much, but it has a significant effect on life, especially in the Arctic where the warmer temperature makes sea ice and glaciers melt more quickly. When most of the glaciers are gone, the Arctic will lose its source of cold, fresh water from the ice, so eventually the Arctic Ocean will become warmer and saltier. We know that the melting ice will have a negative effect on the seals and polar bears that depend on sea ice to hunt and raise pups. At the same time, less ice means that more light can get through to the water, allowing new kinds of algae to grow, photosynthesize, and draw down $\mathrm{CO}_{2}$. The growth of new kinds of algae in warmer water might offset the loss of sea ice algae.

The information we collect about microbes through our experiments will allow us to identify what the microbes eat and the amount of nutrients transferred from algae up to seals. The amount of nutrients larger animals are able to obtain will determine how well they are able to adapt to a changing Arctic Ocean. 


\section{SUMMARY}

In summary, microbes are crucial to the Arctic ecosystem. They carry out key functions including providing food for other organisms and recycling nutrients for reuse by other microbes. The microbes feed larger Arctic animals, which enables the animals to survive the harsh conditions. Microbes reduce the carbon concentration in the atmosphere through carbon drawdown. This helps reduce the warming of our planet. We still do not know enough about what exactly these microbes are, what they do, or how climate change will affect them. Our work is to understand how well Arctic microbes can adapt to climate changes and whether future microbes, as the base of the food web, will provide more or less food for predators, such as fish, whales, and polar bears.

\section{REFERENCES}

1. Bar-On, Y. N., Phillips, R., and Milo, R. 2018. The biomass distribution on earth. Proc. Natl. Acad. Sci. U.S.A. 115:6506-11. doi: 10.1073/pnas.1711842115

2. IPCC. 2018. "Summary for policymakers," in Global Warming of $1.5^{\circ} \mathrm{C}$. An IPCC Special Report on the Impacts of Global Warming of $1.5^{\circ} \mathrm{C}$ Above Pre-industrial Levels and Related Global Greenhouse Gas Emission Pathways, in the Context of Strengthening the Global Response to the Threat of Climate Change, Sustainable Development, and Efforts to Eradicate Poverty, eds V. Masson-Delmotte, P. Zhai, H. O. Pörtner, D. Roberts, J. Skea, P. R. Shukla, et al. (Geneva: World Meteorological Organization). p. 32.

3. Whitman, W. B., Coleman, D. C. and Wiebe, W. J. 1998. Prokaryotes: The unseen majority. Proc. Natl. Acad. Sci. U.S.A. 95: 6578-83.

SUBMITTED: 18 November 2019; ACCEPTED: 05 June 2020; PUBLISHED ONLINE: 15 July 2020.

EDITED BY: Penelope Kate Lindeque, Plymouth Marine Laboratory, United Kingdom

CITATION: Zäncker B, Stern RF, Price EL and Cunliffe M (2020) Reduce, Reuse, Recycle in the Arctic Ocean With the Power of Microbes. Front. Young Minds 8:90. doi: 10.3389/frym.2020.00090

CONFLICT OF INTEREST: The authors declare that the research was conducted in the absence of any commercial or financial relationships that could be construed as a potential conflict of interest.

COPYRIGHT () 2020 Zäncker, Stern, Price and Cunliffe. This is an open-access article distributed under the terms of the Creative Commons Attribution License (CC BY). The use, distribution or reproduction in other forums is permitted, provided the original author(s) and the copyright owner(s) are credited and that the original publication in this journal is cited, in accordance with accepted academic practice. No use, distribution or reproduction is permitted which does not comply with these terms. 


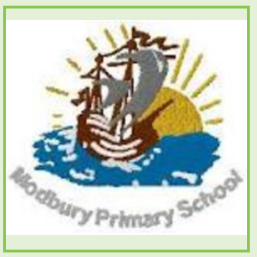

\section{YOUNG REVIEWERS}

\section{MODBURY PRIMARY SCHOOL, AGES: 10-11}

We really enjoyed learning about real-world scientific research and how it is important to help us care for our planet. We are Will, Tom, Jasmine, Jay, Maddie, Angus, Lizzie, Jamie, Matilda, Zoe, Emily, Isaac, Fin, Ella, Martha, and Rose.


\section{AUTHORS}

\section{BIRTHE ZÄNCKER}

I work as a post-doc at the Marine Biological Association in Plymouth, UK, focusing on bacteria and fungi in polar regions. I look at what bacteria and fungi in the sea and the ice eat and how that influences the carbon cycle. In particular I am interested in jelly-like particles (TEP) and their involvement in organic matter transport. To do that, I get to do what I love and go on research cruises to the Arctic and Antarctic. When I am not on a ship, I enjoy being out in nature as well as reading and writing about science and the oceans.

\section{ROWENA F. STERN}

I am a microbial ecologist at the Marine Biological Association. I received a Genetics degree at the University of Aberdeen and a PhD in parasitology from the University of Glasgow. I have worked in medical and ecological research in the UK and Canada. I use genetic methods to identify microbes from historical oceanic samples from as far back as 60 years ago. Using this unique long-term perspective, I am looking at how marine microbes respond to environmental changes over many years, such as those caused by climate change. *rowena.sternamba.ac.uk

\section{ELLIOTT L. PRICE}

I am a marine ecologist with an interest in exploring the impacts of stressors on the structure and dynamics of food webs. As part of the ARISE team within the Changing Arctic Ocean project, I am working toward my Ph.D. looking at how contemporary climate change is affecting mesozooplankton (mid-sized zooplankton) assemblages, primarily copepods, in the Arctic Ocean, and the consequences this may have across the food web.

\section{MICHAEL CUNLIFFE}

I received a degree in environmental biology from the University of Liverpool, and a M.Sc. and Ph.D. in Microbiology from the University of Manchester. After a post-doc at the University of Warwick, I joined the Marine Biological Association (MBA) in 2010 as a Research Fellow. Since 2014, I am a MBA Senior Research Fellow and Associate Professor of Marine Microbiology. I lead a research group at the MBA that studies a range of topics in microbial biology and ecology, from microbe-invertebrate interactions in coastal sediments to microbial biogeochemistry in the open ocean and polar seas.

${ }^{\dagger}$ These authors have contributed equally to this work 